\title{
Copepod-based food webs: auklets and oceanography in the Bering Sea
}

\author{
Alan M. Springer ${ }^{1}$ and David G. Roseneau ${ }^{2}$ \\ 1 Institute of Marine Science, University of Alaska, Fairbanks, Alaska 99701, USA \\ 2 LGL Alaska Research Associates, Inc, P. O. Box 80607, Fairbanks, Alaska 99708, USA
}

\begin{abstract}
The distribution of copepod biomass in the Bering Sea apparently governs the numbers and distribution of nesting least auklets Aethia pusilla, which feed principally on copepods during the breeding season. Least auklets prey on 3 species of large calanoids, 2 characteristic of the outer shelf domain and 1 of the middle shelf domain of the Bering Sea, in proportions determined by their availability. Copepod production in the outer shelf domain is high and relatively tightly coupled to upper trophic levels; thus, competition for copepod biomass may limit the number of auklets in the southeastern Bering Sea. A well developed advective regime across the northern shelf, originating along the continental slope, apparently supplies copepods to the Bering Strait region. Advective replenishment of copepods and absence of significant competition might explain why auklet populations there are much larger than on the southeastern shelf. Recent demographic changes in populations of auklets and piscivorous seabirds suggest possible multispecies interactions among members of copepod-based food webs in the Bering Sea.
\end{abstract}

\section{INTRODUCTION}

A series of 3 physical fronts in the southeastern Bering Sea divides the continental shelf area into 3 hydrographic domains; a fourth domain lies over deep water seaward of the shelf break (see reviews by Iverson et al., 1979; Kinder and Schumacher, 1981a). The 'inner' front is located at approximately the $50 \mathrm{~m}$ isobath (Schumacher et al., 1979); the 'middle' front at the $100 \mathrm{~m}$ isobath (Coachman and Charnell, 1979); and the 'shelf break' front at the $200 \mathrm{~m}$ isobath (Kinder and Coachman, 1978). The fronts derive variously from interactions between tidal mixing, wind mixing and stratification. Interfrontal domains are characterized physically by patterns of vertical structure, temperature and salinity.

Characteristic assemblages of organisms and food webs are found within each domain (Iverson et al., 1979). For example, the middle front limits the crossshelf distribution of zooplankton, particularly of copepods (Cooney, 1981; Smith and Vidal, 1984) which are key elements in the transfer of energy between primary producers and higher trophic levels in regional pelagic food webs (Walsh and McRoy, 1983;

Contribution No. 554, Institute of Marine Science, University of Alaska, Fairbanks, Alaska 99701, USA
Smith and Vidal, 1984). Large, herbivorous copepods, Calanus cristatus, C. plumchrus and Eucalanus bungii, which are restricted to the oceanic and outer shelf domains, account for a greater shunt of carbon through pelagic food webs than do the smaller, less efficient grazers such as Pseudocalanus spp., C. marshallae and Acartia spp., which predominate in the middle shelf domain (Cooney and Coyle, 1982). The most recent estimates of carbon flux from phytoplankton to zooplankton in the southeastern Bering Sea suggest that there is a more than 2 -fold difference in transfer rates between domains, i.e. $68 \mathrm{~g} \mathrm{C} \mathrm{m}^{-2} \mathrm{yr}^{-1}$ in the outer shelf domain and $26 \mathrm{~g} \mathrm{C} \mathrm{m}^{-2} \mathrm{yr}^{-1}$ in the middle shelf domain (Walsh and McRoy, 1983). Thus, the outer shelf domain is dominated by a pelagic food web including walleye pollock Theragra chalcogramma, which now supports the largest single-species fishery in the north Pacific Ocean (Bakkala and Traynor, 1984). The middle domain is dominated by benthic food webs supporting large standing stocks of epifaunal invertebrates (Jewett and Feder, 1981) and the commercially important yellow-finned sole Limanda aspera (Iverson et al., 1979).

Large-scale patterns of copepod distribution corresponding to the outer and middle shelf domains might be expected to influence the distribution of planktivores other than fishes. Least auklets Aethia pusilla 
nest only on offshore islands in the Bering Sea (Sowls et al., 1978) and, during the breeding season, they feed primarily on large calanoid copepods (Bedard, 1969; Searing, 1977; Hunt et al., 1981a). In this paper, we examine the hypothesis that the location of the insular breeding colonies relative to the large hydrographic domains determines the numbers and distribution of least auklet populations, and an alternative hypothesis that invokes interspecific competition and physical processes other than those maintaining hydrographic domains as the more important factors in the biogeography of least auklets in the Bering Sea. We present food habits data of these birds from St. Matthew I. and St. Lawrence I., compare them to similar data from St. Lawrence I. and the Pribilof Is. from other studies, and examine the distribution of least auklets in relation to: (1) the biological domains of the Bering Sea, (2) the distribution of other members of copepod-based food webs in the Bering Sea, and (3) oceanographic features that may act to concentrate prey biomass in the vicinity of breeding colonies.

\section{METHODS}

Least auklet food samples were obtained on St. Lawrence I. in 1981 and on St. Matthew I. in 1982-83 (Fig. 1). Adult birds were collected during the chick period (late Jul to mid-Aug) while returning to the colonies from feeding, or they were trapped at the colonies as they arrived. The contents of the sublingual pouches were removed after collection; trapped birds regurgitated spontaneously. Auklets carry food to chicks in the sublingual pouch and, because it is some distance from the intestinal tract, little digestion takes place between the time the prey are captured and the time they are fed to the chicks. Accurate determinations of the numbers and identities of the various prey taxa consumed are therefore possible.

Prey items were stored in $70 \%$ ethanol in the field and were later identified in the laboratory using preserved reference material and standard taxonomic keys. Prey were measured and assigned to size categories according to Bedard (1969), who determined volume indices (number of individuals of a given taxon $\mathrm{ml}^{-1}$ ) for the principal zooplankton taxa in each size category in auklet diets during his study. The categories are I., 0.0 to $7.0 \mathrm{~mm}$; II., 7.1 to $15.0 \mathrm{~mm}$; and III., > $15.1 \mathrm{~mm}$. Bedard did not report a volume index for Calanus plumchrus so we used his value for $C$. marshallae, a species of similar size. The volume index and number of individuals of each taxon were used to estimate their respective biomass contributions to the total diet.

In order to compare our results on a biomass basis

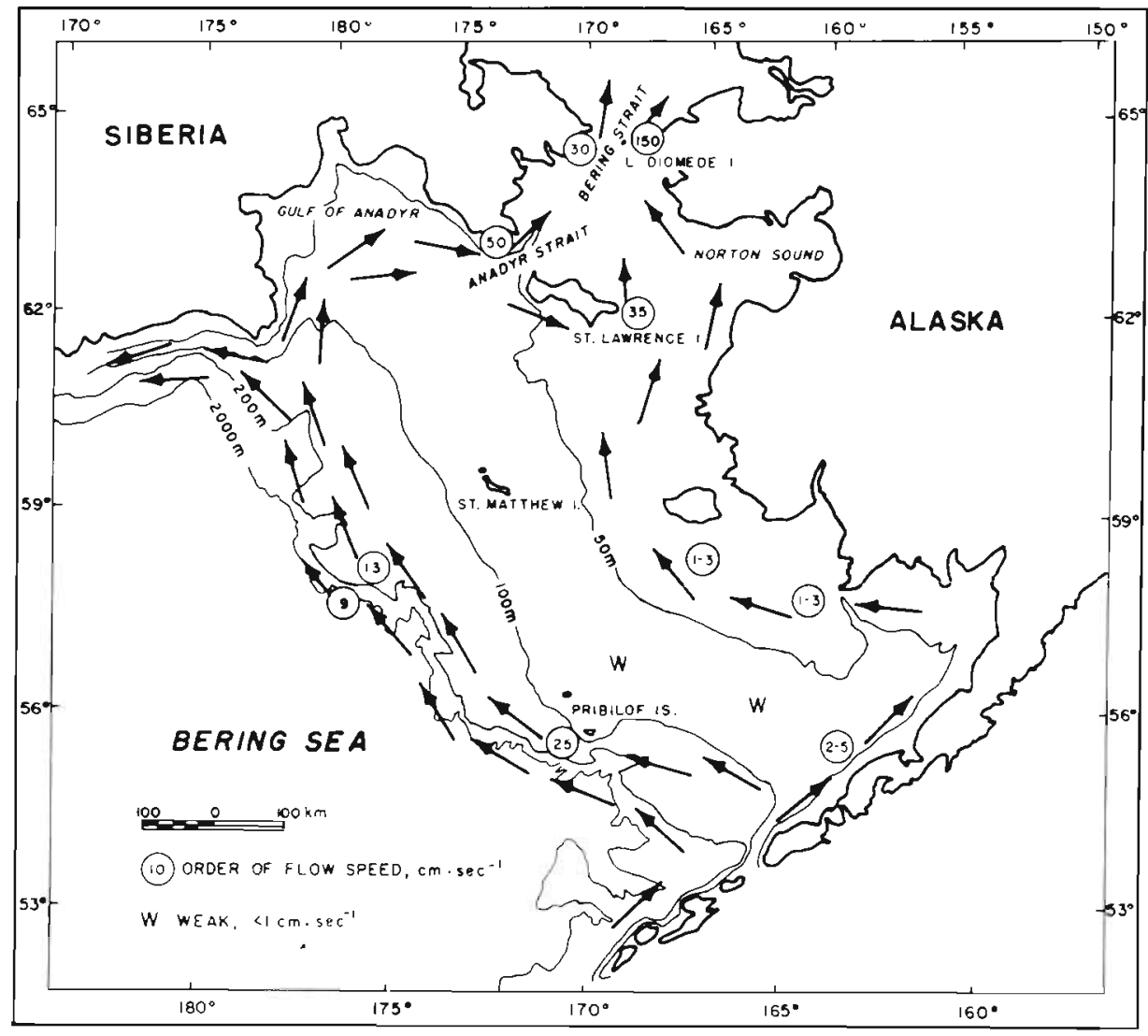

Fig. 1 Locations of principal least auklet colonies in the eastern Bering Sea. Generalized circulation patterns are from Kinder et al. (1975), Kinder and Schumacher (1981b) 
with previous studies, we applied the volume indices to food habits' data from St. Lawrence I. in 1964-66 and 1976 using information on prey numbers and sizes reported by Bedard (1969) and Searing (1977), respectively. Hunt et al. (1981a) reported relative numbers (percentages) of the various prey taxa of auklets on the Pribilofs during 1975-78, but did not report any sizes. Therefore, we estimated the proportions of each taxon in the 3 size categories on the Pribilofs using the mean proportions obtained on St. Matthew I. in 1982-83 and then applied the appropriate volumetric index value to the resulting numbers.

\section{RESULTS AND DISCUSSION}

\section{Food habits}

Prey of least auklets from St. Mathew I. and St. Lawrence I. are listed in Table 1 and Table 2, respectively. Table 2 also contains data from St. Lawrence I. for 1964-1966 (from Bedard, 1969) and for 1976 (from Searing, 1977). Auklet prey from the Pribilof Is. in 1975-78 (from Hunt et al., 1981a) are listed in Table 3.

Copepods contributed by far the greatest biomass to auklet diets on all 3 islands in all years, ranging from

Table 1. Prey of least auklets on St. Matthew I

\begin{tabular}{|lrrrr|}
\hline \multicolumn{1}{c}{ Taxon } & $\begin{array}{c}1982(\mathrm{n}=29) \\
\text { Num- } \\
\text { ber }\end{array}$ & $\begin{array}{c}1983(\mathrm{n}=40) \\
(\%)\end{array}$ & $\begin{array}{c}\text { Num- } \\
\text { ber }\end{array}$ & $\begin{array}{c}\text { Volume } \\
(\%)\end{array}$ \\
\hline Calanus marshallae & 18.658 & 89 & 17,668 & 84 \\
C. plumchrus & 0 & 0 & 1 & $<1$ \\
Hyperiidae & 150 & 5 & 59 & 3 \\
Gammaridae & 216 & 4 & 209 & 9 \\
Decapod zoea & 187 & 1 & 460 & 3 \\
Thysanoessa spp. & 10 & $<1$ & 80 & 1 \\
Limacina helicina & 73 & $<1$ & 8 & $<1$ \\
Other & 1 & $<1$ & 1 & $<1$ \\
\hline
\end{tabular}

about $74 \%$ on St. Lawrence I. in $1964-66$ to about $95 \%$ on St. Lawrence I. in 1976. No other taxon contributed more than about $9 \%$ to prey biomass in any year. Calanus marshallae was essentially the only species of copepod taken by auklets on St. Matthew I.; 1 indi-

Table 3. Prey of least auklets on the Pribilof Is, 1975-78. Numbers (\%) from Hunt et al. (1981a); volume (\%) according to text. $N=258$

\begin{tabular}{|lcc|}
\hline \multicolumn{1}{|c}{ Taxon } & $\begin{array}{c}\text { Number } \\
(\%)\end{array}$ & $\begin{array}{c}\text { Volume } \\
(\%)\end{array}$ \\
\hline Calanus marshallae & 65 & 30 \\
C. plumchris & 11 & 5 \\
C. cristatus & 24 & 48 \\
Hyperiidae & 2 & 9 \\
Gammaridae & 2 & 5 \\
Decapod zoea & 0 & 0 \\
Thysanoessa spp. & $<1$ & 2 \\
Limacina helicina & 0 & 0 \\
Other & 0 & 0 \\
\hline
\end{tabular}

vidual of C. plumchrus was identified. C. marshallae, $C$. plumchrus and $C$. cristatus all contributed importantly to auklet diets on St. Lawrence I. and on the Pribilofs

\section{Relations to hydrographic domains}

St. Matthew I. lies near the center of the middle shelf domain (Fig 1). The nearly exclusive occurrence of Calanus marshallae in auklet diets is consistent with the distributional data on copepods in the southeastern Bering Sea, which show that this species is characteristic of the middle shelf domain but not of the outer shelf or oceanic domains (Cooney, 1981; Smith and Vidal, 1984). Least auklets on St. Matthew I. apparently do not fly as far as the outer shelf domain to feed, a distance of about 40 to $50 \mathrm{~km}$.

The Pribilof Is. are geographically within the middle

Table 2. Prey of least auklets on St. Lawrence I. Data for 1964-66 from Bedard (1969); data for 1976 from Searing (1977)

\begin{tabular}{|c|c|c|c|c|c|c|}
\hline \multirow[t]{2}{*}{ Taxon } & \multicolumn{2}{|c|}{$1964-66(n=124)$} & \multicolumn{2}{|c|}{$1976(n=12)$} & \multicolumn{2}{|c|}{$1981(n=24)$} \\
\hline & Number & Volume (\%) & Number & Volume $(\%)$ & Number & Volume $(\%)$ \\
\hline Calanus marshallae & 77,908 & 65 & 344 & 3 & 3,132 & 26 \\
\hline C. plumchrus & 0 & 0 & 9,047 & 90 & 6,205 & 50 \\
\hline C. cristatus & 1,444 & 8 & 32 & 2 & 197 & 11 \\
\hline Eucalanus bungii & 169 & $<1$ & 9 & $<1$ & 0 & 0 \\
\hline Hyperiidae & 2,102 & 9 & 57 & 1 & 32 & $<1$ \\
\hline Gammaridae & 533 & 3 & 9 & $<1$ & 21 & $<1$ \\
\hline Decapod zoea & 2,808 & 3 & 47 & $<1$ & 643 & 7 \\
\hline Thysanoessa spp. & 2,325 & 7 & 2 & $<1$ & 1 & $<1$ \\
\hline Limacina helicina & 6 & $<1$ & 34 & $<1$ & 3 & $<1$ \\
\hline Other & 311 & 1 & 31 & $<1$ & 0 & 0 \\
\hline
\end{tabular}


shelf domain, but they lie near the middle front. Although Calanus marshallae was numerically dominant in least auklet diets on the Pribilofs, the outer shelf copepods contributed nearly twice as much biomass to auklet diets there, with the most important species being $C$. cristatus, the largest of the calanoid copepods in the Bering Sea.

Prey of least auklets on St. Lawrence I. include species characteristic of both the outer and middle shelf domains as on the Pribilofs. However, St. Lawrence I. lies in shallow water less than $50 \mathrm{~m}$ deep; the $50 \mathrm{~m}$ isobath generally delimits the position of the inner front separating the coastal and middle shelf domains in the southeastern Bering Sea. This apparent inconsistency can be explained by an examination of the flow regime of the Bering Sea, which consists of strong currents across the northern shelf, but which originates far to the south.

Circulation over most of the Bering Sea shelf is characterized by a coastal current and a pattern of transport oriented from southeast to northwest in the middle and outer shelf domains (Fig. 1). Currents are weak except along the shelf break and slope where the Bering Slope Current flows at mean speeds of about 10 to $25 \mathrm{~cm} \mathrm{~s}^{-1}$ i net transport in the Bering Slope Current is about $5 \times 10^{6} \mathrm{~m}^{3} \mathrm{~s}^{-1}$ to the northwest (Kinder et al., 1975). A portion of the flow is entrained in a strong, northward barotropic current passing through Bering Strait (Coachman et al., 1975). The total volume transport averages about $1 \times 10^{6} \mathrm{~m}^{3} \mathrm{~s}^{-1}$ and consists of 3 distinct water masses as defined by 3 temperaturesalinity (T-S) envelopes. Alaskan Coastal Water, originating in Norton Sound, is a warm, low-salinity water mass similar to coastal domain water in the southeastern Bering Sea. Bering Shelf Water and Anadyr Water are both cold, high-salinity water masses originating in the basin of the Bering Sea. Anadyr Water is composed of approximately 80 to $90 \%$ Bering Sea water cooled by the admixture of cold water from the central Gulf of Anadyr during its transit of the outer Gulf; likewise, Bering Shelf Water is thought to be water from the Bering Sea mixed with very cold water resident on the northern shelf (Coachman et al., 1975).

The hydrographic structure of the northern shelf is maintained by density differences between adjoining water masses, which lead to the formation of fronts. In contrast, boundary processes lead to front formation in the southeastern Bering Sea, which then allows the development of distinctive interfrontal hydrographic domains (Iverson et al., 1979; Kinder and Schumacher, 1981a). Thus, the physical processes on the northern shelf are fundamentally different from those in the southeastern Bering Sea.

The consequences of the flow regime for the ecology of the northern shelf are profound. Because a major fraction of the Anadyr/Bering Shelf water apparently remains beneath the pycnocline in summer, $i$. e. below the euphotic zone, nitrate levels remain high during the transit across the shelf. In the vicinity of Bering Strait, nitrate levels between 5 and $16 \mu \mathrm{g}$-at $\mathrm{l}^{-1}$ have been recorded during summer (Husby and Hufford, 1969; McRoy et al., 1972; Sambrotto et al., 1984). Shoaling depths and a narrowing of the channel in Anadyr and Bering Straits constrict the flow and accelerate the currents, leading to vertical eddy coefficients as high as $10 \mathrm{~cm}^{2} \mathrm{~s}^{-1}$ in the Bering Strait region (Coachman et al., 1975). The turbulence is sufficient to raise the nutrient-rich water through the pycnocline into the euphotic zone, creating a functional upwelling system (Fig. 2). Consequently, primary production in the flow field is prolific throughout the summer. Carbon fixation rates between 2 to $4 \mathrm{~g} \mathrm{C} \mathrm{m}^{-2} \mathrm{~d}^{-1}$ have been measured, and the annual production is estimated to be about $325 \mathrm{~g} \mathrm{C} \mathrm{m}^{-2}$ (McRoy et al., 1972; Sambrotto et al., 1984), making this one of the most productive regions in the world.

In comparison, primary production in the outer and middle shelf domains is estimated at only 166 and 162 g C m ${ }^{-2} \mathrm{yr}^{-1}$, respectively (Walsh and McRoy, 1983). Annual production in both domains results primarily from a typical bloom period in spring after the water column has stabilized, and interannual variation in total carbon fixation is a function of the frequency and intensity of summer storms that can disrupt the pycnocline and resupply nutrients to the euphotic zone (Sambrotto et al., in press). As in the case of the physical processes, the primary production regimes of the southeastern shelf and the northern shelf are fundamentally different.

Besides fertilizing the northern shelf waters with nutrients, the flow also seeds the region with zooplankton as indicated by the composition of auklet prey on St. Lawrence I. Endemic Bering Sea zooplankters, including copepods characteristic of the outer shelf domain, have been found far downstream in the eastern Chukchi Sea (Johnson, 1956). Zooplankton grazers cannot control the growth of phytoplankton, however, which leads to a major benthic flux of carbon and explains the high standing stocks of benthic invertebrate macrofauna on the Bering/Chukchi shelf as reported by Stoker (1981) In this regard the northern shelf is similar to the middle shelf, where nearly $80 \%$ of the annual primary production enters the detritus pool (Walsh and McRoy, 1983)

\section{Interspecific competition for copepods}

Walleye pollock reach their greatest density in the outer shelf domain, although some, principally 1 yr-old 


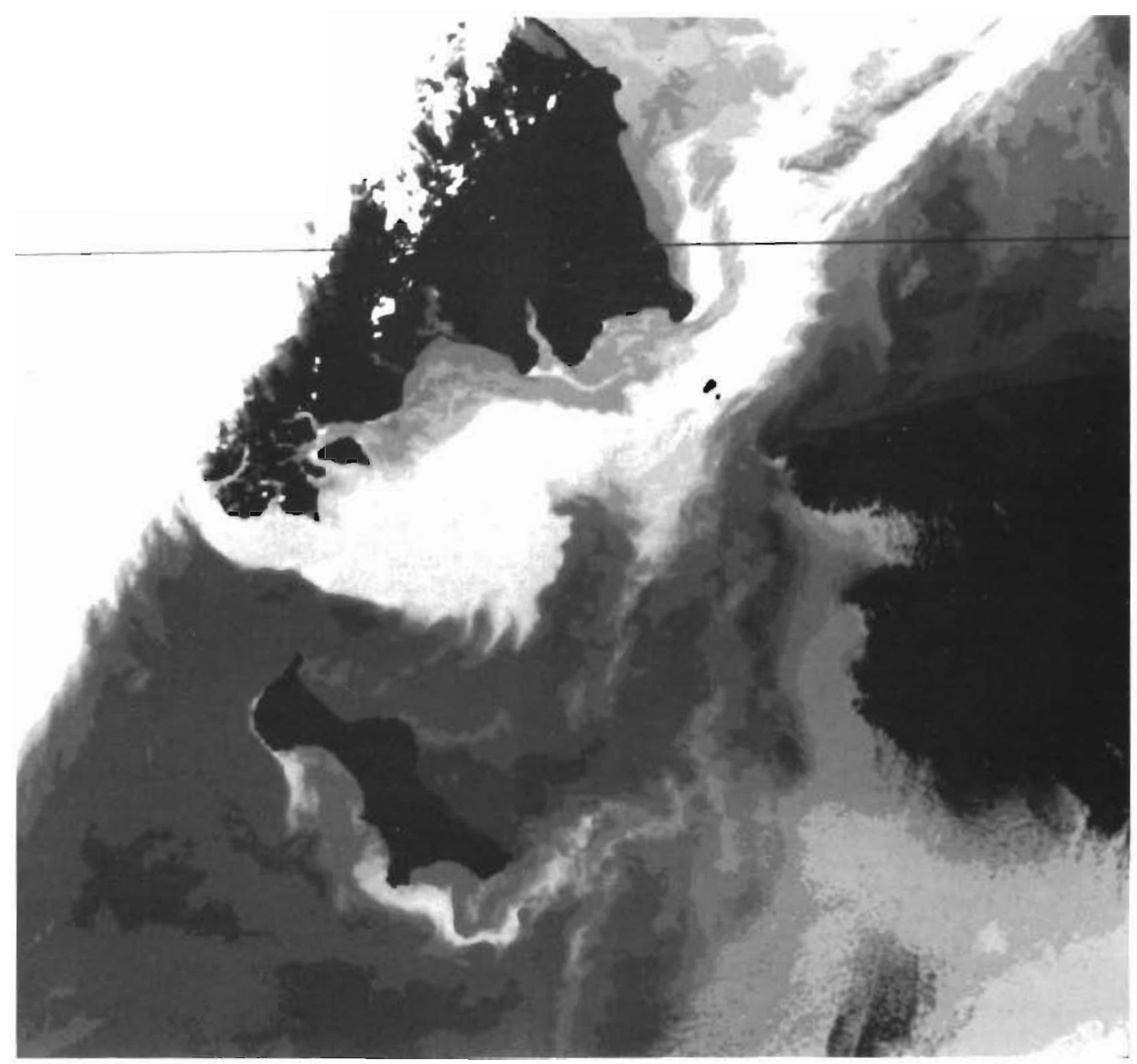

Fig. 2. Water mass distribution in the Bering Strait region. Turbulence raises cold Anadyr/Bering Shelf water (light shading) to the surface northwest of St. Lawrence I. and through Bering Strait: upwelling of Anadyr/Bering Shelf water along the southwest coast of St. Lawrence I. is also pronounced. Warn Alaskan Coasta] Water follows the mainland from Norton Sound (obscured by clouds) through the eastern Chukchi Sea. NOAA 4 infrared imagery; temperature scale is $-3^{\circ}$ to $12^{\circ} \mathrm{C}$

fish, range well onto the middle shelf (Smith, 1981) Spawning occurs predominantly along the southeast outer shelf and 0 age-class juveniles have been found in large numbers in the vicinity of the Pribilof Is (Smith, 1981). The diet of the larvae consists mainly of copepod nauplii, changing to larger copepodids, adult copepods and other zooplankton during the first year (Clarke, 1978; Smith, 1981; T. Nishyama, unpubl.) Whales, primarily fin whales Balaenoptera physalus are common in the southeastern Bering Sea and along the shelf break (Nasu, 1974) where they feed on copepods as well as other zooplankters (Nemoto, 1957 1959). Pollock and whales are, therefore, direct competitors with auklets for copepod biomass. Smith and Vidal (1984) suggested that declines in numbers of Calanus plumchrus and $C$. cristatus from the outer shelf domain during spring represent losses to verte- brate predators. A decline of about $80 \%$ in survivorship of these copepods occurred during April-May, pre-dating the onset of egg-laying by auklets at the colonies and possibly affecting the size of the auklet population.

Pollock are rarely found on the northern shelf, where they are replaced by Arctic cod Boreogadus saida and saffron cod Eleginus gracilis (Wolotira et al., 1979; Frost and Lowry, 1981a). Probably because of harsher environmental conditions, populations of these cods, as well as of other fishes, are small compared to those in the southeastern Bering Sea as indicated by test fishery data (Wolotira et al., 1979) and by the absence of a commercial fishery on the northern shelf. In summer, the baleen whales are represented by the gray whale Eschrichtius robustus, which feeds primarily on benthic amphipods (Frost and Lowry, 1981b). Thus 
competition among auklets, whales and fishes for copepods is probably low compared to that in the outer shelf domain.

Pollock is the largest contributor of biomass to diets of piscivorous seabirds on the Pribilots (Hunt et al., 1981a) and St. Matthew I. (Springer et al., in press, unpubl.). On St. Lawrence I., piscivorous seabirds feed on an variety of fishes including Arctic cod, sand lance Ammodytes hexapterus and capelin Mallotus villosus (Springer and Roseneau, unpubl.). The ratio of the numbers of murres (Uria spp.), the numerically dominant avian piscivores at Bering Sea breeding colonies, to the numbers of least auklets (Fig. 3) indicates a shift

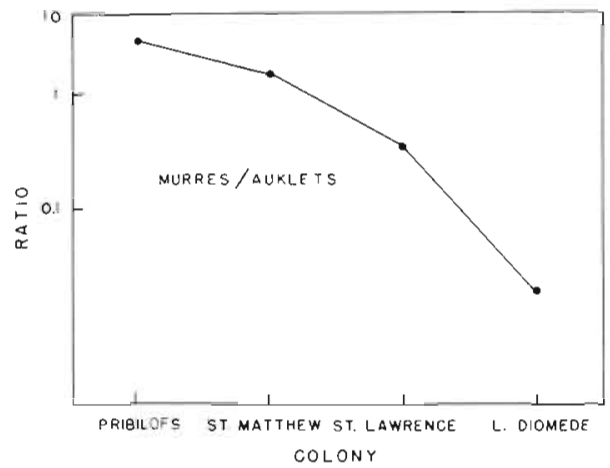

Fig. 3. Relative numbers of murres and least auklets at colonies in the Bering Sea. From Sowls et al. (1978) and Roseneau et al. (in press)

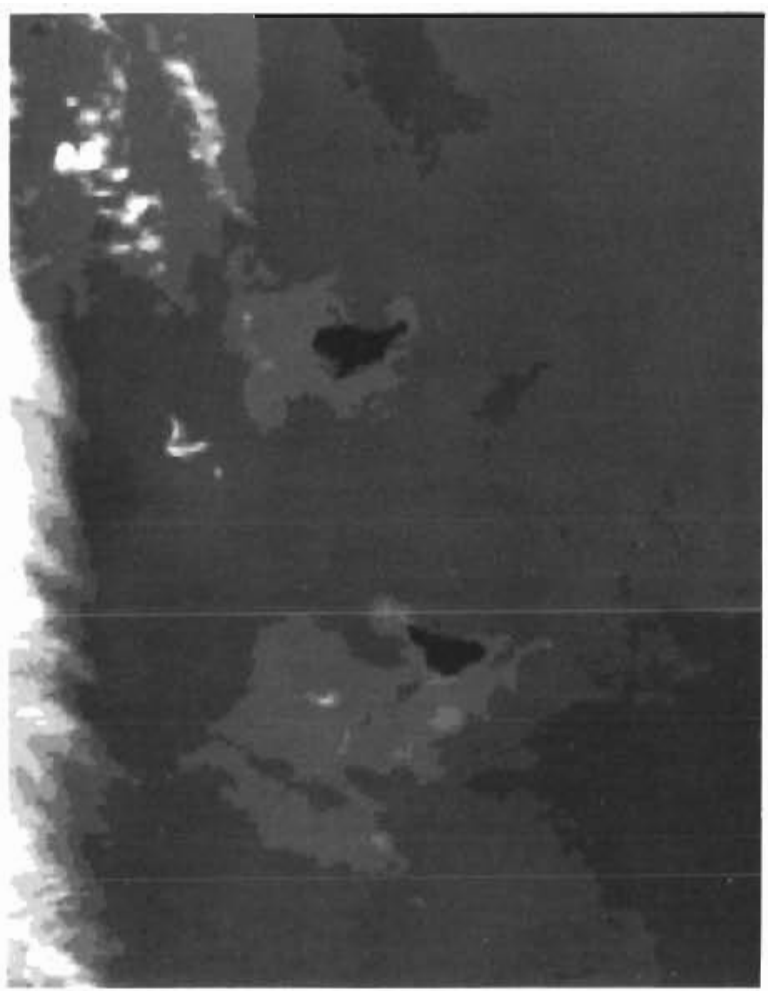

in the proportions of available fish and copepod biomass from predominantly fish in the southeast to predominantly copepods in the north. This trend is consistent with the reported distribution of pollock and with the inferred competition for copepods in the southeastern Bering Sea

\section{Local physical features}

Areas of cold, upwelled water surrounding the Pribilofs and St. Matthew I. are common features in summer (Fig. 4). Kinder et al. (1983) found the edge of this zone around St. Paul I. (Pribilof Is.) to correspond to a front approximately at the $50 \mathrm{~m}$ isobath. The density of feeding murres was significantly higher at the front surrounding St. Paul I. than in nearby waters on either side of it. Auklets showed no association with the front but were all within the area of well-mixed water between the front and the island. Such observations indicate that zooplankton and possibly fishes are also relatively more abundant within the mixed zone and in the front, a conclusion supported by numerous examples of the enhancement of productivity and biomass in similar situations elsewhere (e. g. Owen, 1981). During early August 1983 on St. Matthew I., southerly winds apparently caused strong, localized upwelling along the northeastern coastline as indicated by a shift in the

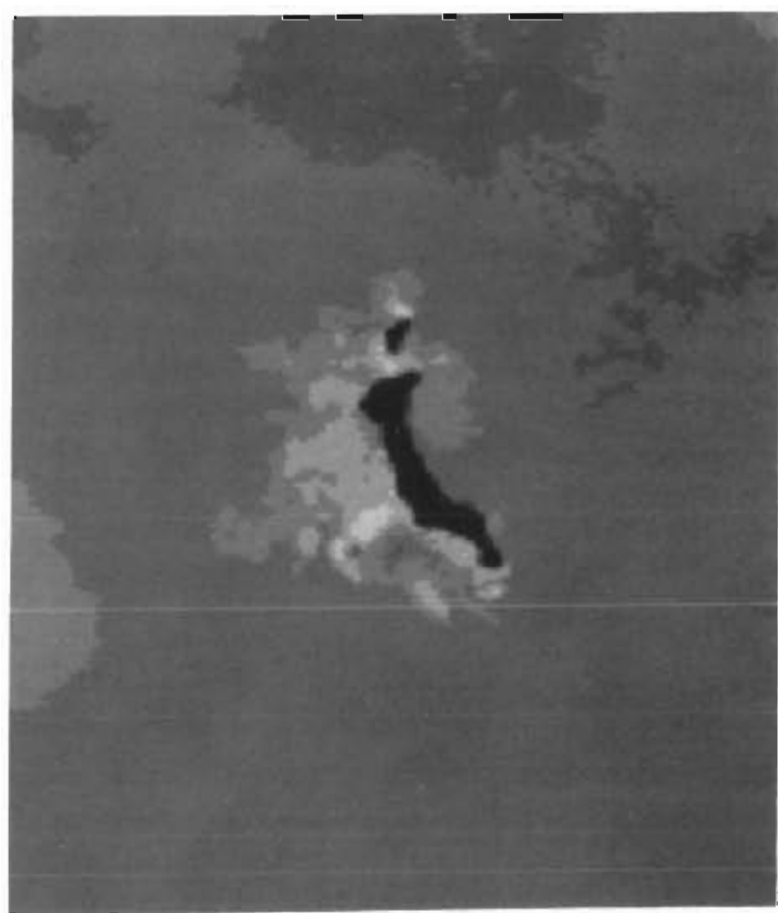

Fig. 4. Upwelling around the Pribilof Is. (left) and St. Matthew I. (right). Cold water =light shading. NOAA 4 infrared imagery; temperature enhancement scale is $-3^{\circ}$ to $12^{\circ} \mathrm{C}$ 
feeding areas of least auklets from offshore north and northeast of the island to a zone within $10 \mathrm{~m}$ to about $1 \mathrm{~km}$ of shore. The majority of least auklets nesting on the northeastern side of island fed in this zone during that time. Horizontal plankton tows taken in the upper $10 \mathrm{~m}$ of the water column nearshore during the upwelling episode contained primarily Pseudocalanus spp., Acartia longiremis and Calanus marshallae in densities on the order of $10^{4} \mathrm{~m}^{-3}, 400 \mathrm{~m}^{-3}$ and $200 \mathrm{~m}^{-3}$, respectively.

Upwelling at the edge of St. Lawrence I. (Fig. 2) is also common. It occurs during periods of strong northeasterly winds that establish Ekman transport offshore on the west side of the island, and possibly under other conditions as well. Bedard (1969) first pointed out the effect that this process has on feeding auklets on St. Lawrence I.: during upwelling, the birds fed intensively along the western shoreline; at other times, they fed over a broad area offshore. In 1981 we saw a similar episode when auklets shifted their feeding from generally north of the island in Anadyr Strait to the western coast line within $12 \mathrm{~h}$ after the onset of strong northeasterly winds. Growth rates of least auklet chicks during upwelling were significantly greater than when the birds fed elsewhere (Roseneau et al., in press). The prey taken near shore was similar to that from Anadyr Strait, consisting primarily of the outer shelf Calanus plumchrus (Table 4). In contrast, the smaller number of auklets that fed south of the island, apparently outside of the area affected by upwelling, fed mainly on the middle shelf $C$. marshallae.

\section{CONCLUSIONS}

The physical and biological characteristics of the continental shelf of the southeastern Bering Sea are fundamentally different from those of the northern shelf. The formation of fronts over the southeastern shelf leads to the development of distinctive domains by restricting cross-shelf advective and diffusive processes governing the distribution of nutrients and biota. In contrast, on the northern shelf the juxtaposi-

Table 4 . Comparison of copepod prey of least auklets feeding in 3 areas near St. Lawrence I. Number of individuals ( $\%$ volume)

\begin{tabular}{|lrrrr|}
\hline \multicolumn{1}{|c|}{ Area } & $\begin{array}{c}\text { Palanus } \\
\text { marshallae }\end{array}$ & $\begin{array}{c}\text { Calanus } \\
\text { plumchrus }\end{array}$ & $\begin{array}{r}\text { Calanus } \\
\text { cristatus }\end{array}$ \\
\hline Anadyr Strait & $266(6)$ & $3,210(74)$ & $130(20)$ \\
Nearshore, W coast & $185(6)$ & $2,395(79)$ & $67(15)$ \\
SW of island & $2,576(81)$ & $600(19)$ & 0 \\
\hline
\end{tabular}

tion of water masses with differing physical properties creates fronts between them, and the role of advection is paramount in creating a domain with prolific primary production and a well developed copepod-based food web. Thus, the advective domain on the northwest shelf, the 'northwest shelf domain', should not be thought of as an extension of the domains on the southeastern shelf even though both regions contain many of the same species of marine organisms and similar food webs.

The location of the offshore islands in the Bering Sea relative to the major hydrographic domains apparently is a criterion determining the numbers of least auklets at breeding colonies. The distribution of the principal copepod prey species, however, is a less important factor than is the distribution of copepod biomass. Copepod biomass could be affected by predation pressure and by physical features that act to concentrate the animals in the vicinity of the island colonies. Examples of such physical mechanisms are insular upwelling and associated local frontal systems like those around the Pribilof Is. and St. Matthew I., and the presence of the Bering Slope Current that sweeps outer shelf zooplankton, including copepods, onto the northern shelf.

The relation between numbers of piscivorous murres and planktivorous auklets at breeding colonies in the Bering Sea suggests a gradient in the relative proportions of fish and copepod biomass available to avian consumers: there are relatively more murres in the southern Bering and more auklets in the northern Bering. Competition with vertebrate copepod consumers in the outer shelf domain could limit the number of auklets there, while the absence of competition in the northwest shelf domain might explain, in part, the immense auklet populations in the Anadyr Strait/Bering Strait region. Differences in the relative proportions of nesting habitat available to auklets and murres on the islands (talus for auklets and cliffs for murres) might contribute to the differences in species composition, although the effect is probably secondary to that of differential prey abundance.

If pollock act to enhance populations of piscivores and depress populations of other planktivores, declines in the abundance of pollock in the past decade (Bakkala and Traynor, 1984) could account for recent patterns in the reproductive success and numerical trends in seabird populations in the Bering Sea. Between 1969 and 1973 the catch per unit effort (CPUE) of the commercial pollock fishery in the southeastern Bering fell by about $70 \%$, suggesting a significant decline in the pollock population. The CPUE has not recovered since then. The reproductive success of black-legged kittiwakes Rissa tridactyla, a piscivorous gull that also feeds on pollock, on the Pribilofs 
during the late 1970's (Hunt et al, 1981b) was relatively low compared to other colonies in Alaska during the same time (Springer et al., in press). Kittiwakes on the Pribilofs and St. Matthew I. have had very low reproductive success since 1981 (Springer et al., in press; Roseneau, unpubl.). In contrast, the least auklet population on St. Lawrence I nearly doubled between 1966 and 1976 (Searing, 1977) and, between 1976 and 1982, least auklet numbers on the Pribilof Is. may have increased also (Craighead and Oppenheim, in press). Similar multispecies interactions have been reported elsewhere and often signal changes in ecosystems of major proportions (May et al., 1979; Vesin et al., 1981).

Acknowledgements. We thank B. Cooper, S. Cooper, E. Hoberg, M. Hoberg and P. Martin for assisting on field work on St. Matthew I; K. Coyle for identifying auklet prey; $T$ Cooney, J. Goering and T. Nishyama for commenting on the manuscript; the Gambell and Savoonga Native Corporations for granting access to St. Lawrence I.; and G. White for providing satellite imagery. This study was funded by the Minerals Management Service through interagency agreement with the National Oceanic and Atmospheric Administration, as part of the Outer Continental Shelf Environmental Assessment Program. Additional support was provided by National Science Foundation Grant DPP-8300916.

\section{LITERATURE CITED}

Bakkala, R. G., Traynor, J. J. (1984). Walleye pollock. In Bakkala, R. G., Low, L-L. (ed.) Condition of ground fish resources of the eastern Bering Sea and Aleutian Island region in 1983. NOAA Tech. Memo. NMFS F/NWC-53, NTIS, U. S. Dept. Comm., Springfield, Virginia, p. 1-20

Bedard, J. (1969). Feeding of the least, crested, and parakeet auklets around St. Lawrence Island, Alaska. Can. J. Zool. 47: $1025-1050$

Clarke, M.E. (1978). Some aspects of the feeding of larval walleye pollock (Theragra chalcogramma, Pallas) in the southeast Bering Sea. M. Sc. thesis, University of Alaska, Fairbanks

Coachman, L. K., Aagaard, K., Tripp, R. B. (1975). Bering Strait: the regional physical oceanography. University Washington Press, Seattle

Coachman, L. K., Charnell, R. L. (1979). On lateral water mass interaction - a case study, Bristol Bay, Alaska. J. phys. Oceanog. 9: 278-297

Cooney, R. T. (1981). Bering Sea zooplankton and micronecton communities with emphasis on annual production. In: Hood, D. W. Calder, J. A. (ed.) The eastern Bering Sea shelf: oceanography and resources, Vol. 2. Office of Marine Pollution Assessment, NOAA, Juneau, Alaska, p. 947-974

Cooney, R. T., Coyle, K. O. (1982). Trophic implications of cross-shelf copepod distributions in the southeastern Bering Sea. Mar Biol. 70: 187-196

Craighead, F. L., Oppenheim, J. (in press). Population estimates and temporal trends of Pribilof Islands seabirds. In: Environ. Assess. Alaskan Cont. Shelf, Final Rep. Prin. Invest., MMS/NOAA, OCSEAP, Boulder, Colorado

Frost, K. J., Lowry, L. F. (1981a). Trophic importance of some marine gadids in northern Alaska and their body-otolith size relationships. Fish. Bull. U. S. 79: 187-192
Frost, K. J., Lowry, L. F. (1981b). Foods and trophic relationships of cetaceans in the Bering Sea. In: Hood, D. W., Calder, J. A. (ed.) The eastern Bering Sea shelf: oceanography and resources, Vol. 2. Office of Marine Pollution Assessment, NOAA, Juneau, Alaska, p. 925-936

Hunt, G. L., Jr., Burgeson, B., Sanger, G. A. (1981a). Feeding ecology of seabirds of the eastern Bering Sea. In: Hood, D. W. Calder, J. A. (ed.) The eastern Bering Sea shelf: oceanography and resources, Vol. 2. Office of Marine Pollution Assessment, Juneau, Alaska, p. 629-648

Hunt, G. L., Jr., Eppley, Z., Drury, W. H. (1981b). Breeding distribution and reproductive biology of marine birds in the eastern Bering Sea. In: Hood, D. W., Calder, J. A. (ed.) The eastern Bering Sea shelf: oceanography and resources, Vol. 2. Office of Marine Pollution Assessment, Juneau, Alaska, p. 649-688

Husby, D. M., Hufford, G. L. (1969). Oceanographic investigation of the northern Bering Sea and Bering Strait, 8-21 June 1969. U. S. Coast Guard Oceanogr. Rep. No. 42, CG 373 42, Washington D. C

Iverson, R. L., Coachman, L. K., Cooney, R. T., English, T. S., Goering, J. J., Hunt, G. L., Jr., Macauley, M. C., McRoy. C. P., Reeburg, W. S., Witledge, T. E. (1979). Ecological significance of fronts in the southeastern Bering Sea. In: Livingston, R. J. (ed.) Ecological processes in coastal and marine systems. Plenum Press, New York, p. 437-466

Jewett, S. C., Feder, H. M. (1981). Epifaunal invertebrates of the continental shelf of the eastern Bering and Chukchi seas. In: Hood, D. W., Calder, J. A. (ed.) The eastern Bering Sea shelf: oceanography and resources, Vol. 2. Office of Marine Pollution Assessment, Juneau, Alaska, p. $1131-1154$

Johnson, M.W. (1956). The plankton of the Beaufort and Chukchi sea areas of the Arctic and its relation to the hydrography. Arctic Inst. N. America Tech. Paper No. 1., Montreal

Kinder, T. H., Coachman, L. K. (1978). The front overlying the continental slope in the eastern Bering Sea. J. geophys. Res. 83: 4551-4559

Kinder, T H., Coachman, L. K., Galt, J. A. (1975). The Bering slope current system. J. phys. Oceanogr. 5: 231-244

Kinder, T H., Hunt, G. L., Schneider, D., Schumacher, J. D. (1983). Correlations between seabirds and oceanic fronts around the Pribilof Islands, Alaska. Estuar. coast. Shelf Sci. 16: 309-319

Kinder, T. H., Schumacher, J. D. (1981a). Hydrographic structure over the continental shelf of the southeastern Bering Sea. In: Hood, D. W. Calder, J. A. (ed.) The eastern Bering Sea shelf: oceanography and resources, Vol. 1. Office of Marine Pollution Assessment, NOAA, Juneau, Alaska, p. $31-52$

Kinder, T H., Schumacher, J. D. (1981b). Circulation over the continental shelf of the southeastern Bering Sea. In: Hood, D. W., Calder, J. A. (ed.) The eastern Bering Sea shelf: oceanography and resources, Vol. 1. Office of Marine Pollution Assessment, NOAA, Juneau, Alaska, p. 53-75

May, R. M., Beddington, J. R., Clark, C. W., Holt, S. J., Laws, R. M. (1979). Management of multispecies fisheries. Science, N. Y 205: 267-277

McRoy, C. P., Goering, J. J., Shiels, W. S. (1972). Studies of primary production in the eastern Bering Sea. In: Takenouti, A. Y et al. (ed.) Biological oceanography of the northern North Pacific Ocean. Motoda Commemorative, Vol. 3. Idemitsu Shoten, Tokyo, p. 199-216

Nasu, K. (1974). Movement of baleen whales in relation to hydrographic conditions in the northern part of the North Pacific Ocean and the Bering Sea. In: Hood, D. W., Kelley. 
E. J. (ed.) Oceanography of the Bering Sea. Inst. Mar. Sci. University of Alaska. Fairbanks, Alaska, p. 345-36

Nemoto, T. (1957). Foods of baleen whales in the northern Pacific. Sci. Rep. Whales Res. Inst. 12: 33-89

Nemoto, T (1959). Food of baleen whales with reference to whale movements. Sci. Rep. Whales Res. Inst. 14: 149-290

Owen, R. W (1981). Fronts and eddies in the sea: mechanisms, interactions and biological effects. In: Longhurst, A. R. (ed.) Analysis of marine ecosystems. Academic Press, New York, p. 197-233

Roseneau, D. G., Springer, A. M., Murphy, E. C., Springer, M. I. (in press). Population and trophics studies of seabirds in the northern Bering and eastern Chukchi seas, 1981. In: Environ. Assess. Alaskan Cont. Shelf, Final Rep. Prin. Invest., MMS/NOAA OCSEAP, Boulder, Colorado

Sambrotto, R. N., Goering, J. J., McRoy, C. P. (1984). Large yearly production of phytoplankton in western Bering Strait. Science 225: 1147-1150

Sambrotto, R. N., Niebauer, H. J. Goering, J. J., Iverson, R. L. (in press). Relationships among vertical mixing, nitrate uptake and phytoplankton growth during the spring bloom in the southeast Bering Sea. Cont. Shelf Res.

Schumacher, J. D., Kinder, T H., Pashinski, D. J., Charnell, R. L. (1979). A structural front over the continental shelf of the eastern Bering Sea. J. phys. Oceanogr. 9: 79-87

Searing, G. (1977). Some aspects of the ecology of cliffnesting seabirds at Kongkok Bay, St. Lawrence Island, Alaska, during 1976. In: Environ. Assess. Alaskan Cont. Shelf, Annu. Rep. Prin. Invest., Vol. 5. MMS/NOAA OCSEAP, Boulder, Colorado, p. 263-412

Smith, G. B. (1981). The biology of walleye pollock. In: Hood, D. W., Calder, J. A. (ed.) The eastern Bering Sea shelf: oceanography and resources, Vol. 1 Office of Marine Pollution Assessment, Juneau, Alaska, p. 527-551

Smith, S. L., Vidal, J. (1984). Spatial and temporal effects of salinity, temperature and chlorophyll on the communities of zooplankton in the southeastern Bering Sea. J. mar. Res. 42: 221-257

Sowls, A. L., Hatch, S. A., Lensink, C. J. (1978). Catalog of Alaskan seabird colonies. Biol. Serv. Prog., U. S. Fish and Wildlife Service, Anchorage, Alaska

Springer, A. M., Roseneau, D. G., Murphy, E. C., Springer, M. I. (in press). Population and trophic studies of seabirds in the northern Bering and eastern Chukchi seas, 1982. In: Environ. Assess. Alaskan Cont. Shelf, Final Rep. Prin. Invest., MMS/NOAA OCSEAP, Boulder, Colorado

Stoker, S. (1981). Benthic invertebrate macrofauna of the eastern Bering/Chukchi continental shelf. In: Hood, D. W., Calder, J. A. (ed.) The eastern Bering Sea shelf: oceanography and resources, Vol. 2. Office of Marine Pollution Assessment, Juneau, Alaska, p. 1069-1090

Vesin, J. P., Leggett, W. C., Able, K. W. (1981). Feeding ecology of capelin (Mallotus villosus) in the estuary and western Gulf of St. Lawrence and its multispecies implications. Can. J. Fish. aquat. Sci. 38: 257-267

Walsh, J. J., McRoy, CP. (1983). Ecosystem analysis and synthesis in the southeastern Bering Sea. PROBES Final Progress Report. University of Alaska, Fairbanks

Wolotira, R. J., Sample, T. M., Morin, M. J. (1979). Baseline studies of fish and shellfish resources of Norton Sound and the southeastern Chukchi Sea. In: Environ. Assess. Alaskan Cont. Shelf, Final Rep. Prin. Invest., Vol. 6. MMS/ NOAA OCSEAP, Boulder, Colorado, p. 258-572

This paper was presented by Professor T. R. Parsons; it was accepted for printing on October 2, 1984 